\title{
NIH ponders issues of scale in protein push
}

Erika Check, Washington

The US National Institutes of Health (NIH) faces a tough balancing act between funding large institutes and supporting individual laboratories in the still-emerging discipline of proteomics, said scientists at a workshop on the topic.

Twenty-four senior researchers were invited to the NIH campus in Bethesda, Maryland, late last month to tell its managers how best to invest in proteomics, which seeks to establish the structure and function of all human proteins. But the limitless scope of such an enterprise clearly perplexed some of the participants, many of whom voiced suspicion of any large-scale approach akin to the Human Genome Project.

In theory, proteomics could encompass the study of all known human proteins, complexes of proteins, and interactions of proteins with small molecules. But unravelling such a vast array of information in a systematic way would require new and expensive technologies. And although some researchers at the workshop argued that the NIH should invest in large centres that would develop and exploit such technologies, most said that they

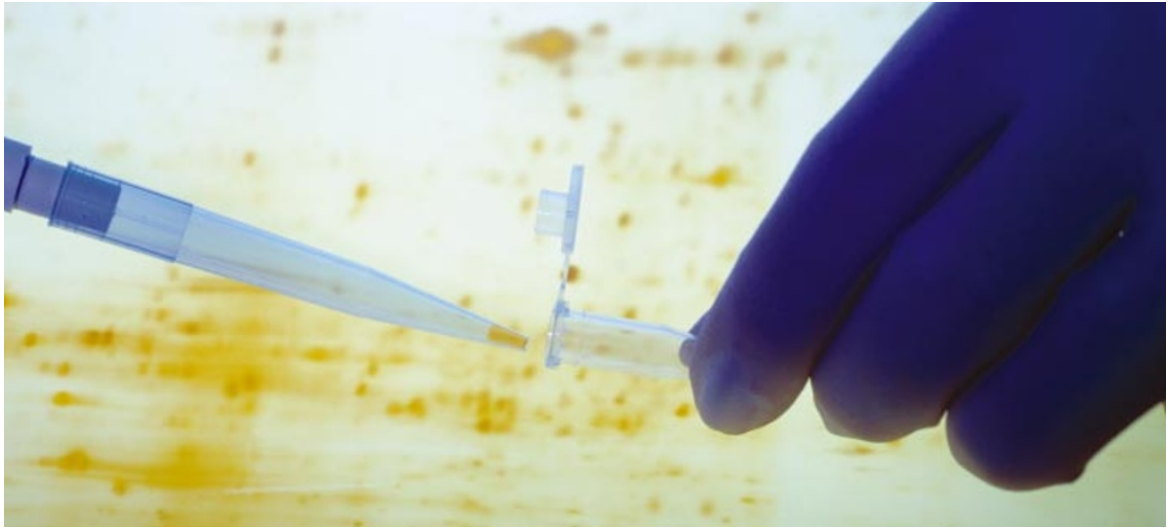

Drip-feed or deluge? Researchers are at odds over the best way to generate data on human proteins.

favour approaches that would encourage individual investigators to study small parts of large, complex protein networks.

Several delegates voiced concern that a high-throughput approach to finding proteins would be hugely expensive but yield little insight. John Yates, a mass-spectrometry specialist at the Scripps Research Institute in La Jolla, California, dismissed some such efforts as "low-IQ proteomics".

\section{Phoenix rises to genomic challenge}

\section{Rex Dalton, San Diego}

A major facility that will perform large-scale gene-expression analysis on tissue samples and release its findings to the public is set to be established in Phoenix, Arizona.

The board of the International Genomics Consortium - a broad group of pharmaceutical companies, universities and other backers that will operate the facility (see Nature 410,$855 ; 2001$ ) - is expected to announce within the next month that the centre will be built in Phoenix and directed by Jeffrey Trent, currently scientific director of the National Human Genome Research Institute, part of the National Institutes of Health (NIH), at Bethesda, Maryland.

The consortium has already attracted more than \$42.5 million from pharmaceutical companies and foundations to advance its first genomic project on cancer. And discussions already are under way to expand the work to other diseases, including Alzheimer's, multiple sclerosis, diabetes and heart and lung disorders.

In the past year, 19 major US medical centres have agreed to provide the consortium with samples of malignant and normal tissue for gene-expression analysis. Genetic data would then be available for use by any scientist worldwide - with no intellectual property restrictions attached. The concept will be similar to that of the SNP Consortium, a non-profit, public-private group set up in 1999 to provide researchers with singlenucleotide polymorphisms, the common variations in human DNA.

At the genomic consortium, microarray analysis will be done on DNA samples from tumours and normal tissue. The resultant expression records of the messenger RNA turned on in the tissue samples will be made available to researchers on the consortium's open database.

The consortium was the idea of Richard Mallery, a Phoenix-based lawyer who chairs its board, and has won support from others who want to expand research and biotechnology in Arizona. The state of Arizona and other local backers are putting together an incentive package worth tens of millions of dollars to help support the facility. The state legislature is expected to pass the necessary financing measures this month.

Other locations, including Atlanta and Baltimore, were considered for the project but Phoenix was always top of the list. Trent, the consortium's chief scientific adviser, has wanted to return to his home state to lead the venture. He says he hasn't yet given official notice that he will leave the NIH, but adds that this could happen shortly.

www.intgen.org
Other researchers argued that without uniform standards, such as the ones that have been adopted for gene microarrays, even existing data on proteins will be difficult to replicate between laboratories. Still others said that large data sets will prove useless without individual investigators who are motivated to wade through them to gain new insights into their favourite systems.

"We need a benevolent champion for individual molecules," said Steve Clarke, a biochemist at the University of California, Los Angeles (UCLA). "We have tremendous amounts of information already and so much of it goes unused."

But others declared support for a 'bigscience' approach to the subject. Ruedi Aebersold, a co-founder of the Institute for Systems Biology in Seattle, Washington, joined Peer Bork of the European Molecular Biology Laboratory, Heidelberg, in advocating large-scale protein profiling. They said that the NIH should set up pilot centres stocked with mass spectrometers that would profile the proteins expressed in the bodies of healthy and sick patients.

Other participants questioned whether individual researchers will be able to use the data generated by high-throughput technologies. "How are we going to connect all these data sets to the laboratories of the people asking the questions?" asked William Studier, a structural-genomics expert at the Brookhaven National Laboratory in New York state.

David Eisenberg, director of the US Department of Energy's Laboratory of Structural Biology and Molecular Medicine at UCLA, said: "I think there was consensus that it's probably not going to be possible to have a scaled-up human proteomics project in the next couple of years."

NIH managers attending the workshop included Francis Collins, director of the National Human Genome Research Institute, who said he would use its guidance to help frame his institute's next five-year plan, which is due out next spring. 